\title{
PENGENALAN JENIS TANAMAN MANGGA BERDASARKAN BENTUK DAN TEKSTUR DAUN MENGGUNAKAN KECERDASAN ARTIFISIAL $K$-NEAREST NEIGHBOR (KNN) DAN FUSI INFORMASI
}

\author{
Arwin Datumaya Wahyudi Sumari*1, Muhammad Rifky Syahbana ${ }^{2}$, Mustika Mentari ${ }^{3}$ \\ ${ }^{1}$ Cognitive Artificial Intelligence Research Group (CAIRG), Program Studi Magister Terapan Teknik Elektro, \\ Jurusan Teknik Elektro, Politeknik Negeri Malang \\ ${ }^{2,3}$ Program Studi Teknik Informatika, Jurusan Teknologi Informasi, Politeknik Negeri Malang \\ ${ }^{1}$ Lanud Abdulrachman Saleh, Komando Operasi Angkatan Udara II, TNI Angkatan Udara \\ Email: ${ }^{1}$ arwin.sumari@polinema.ac.id, ${ }^{2}$ rifkysyahbana123@gmail.com, ${ }^{3}$ must.mentari@ polinema.ac.id \\ "Arwin Datumaya Wahyudi Sumari \\ *Penulis Korespondensi
}

(Naskah masuk: 23 November 2020, diterima untuk diterbitkan: 21 Juli 2021)

\begin{abstract}
Abstrak
Memilih tanaman Mangga yang sesuai dengan yang diinginkan menjadi sebuah tantangan dihadapkan pada ragam tanaman marga Mangifera yang ada saat ini. Kesalahan pemilihan jenis tanaman Mangga dapat berujung pada kekecewaan pembeli dan menurunkan kepercayaan kepada penjual karena dapat dianggap memberikan jenis tanaman yang salah. Hal ini terjadi karena jenis tanaman Mangga hanya dapat diketahui setelah berbuah. Dalam upaya mereduksi kesalahan tersebut, maka dirancang dan dibangun sebuah sistem pencitraan digital untuk pengenalan jenis tanaman Mangga berdasarkan bentuk dan tekstur daun menggunakan Kecerdasan Artifisial K-Nearest Neighbor (KNN) yang digabungkan dengan Fusi Informasi guna mempercepat klasifikasi dengan hasil klasifikasi yang konsisten. Data citra terdiri atas empat macam daun tanaman Mangga yakni jenis Gadung, Lalijiwo, Golek dan Irwin. Fitur tekstur daun diekstraksi menggunakan metode Local Binary Pattern (LBP) dan Entropi, sedangkan fitur bentuk daun diekstraksi menggunakan metode Rectangularity. Kedua fitur tersebut difusikan sebagai masukan bagi pengklasifikasi KNN. Berdasarkan dari hasil-hasil pengujian, KNN berhasil mengenali keempat jenis tanaman Mangga tersebut dengan akurasi tertinggi sebesar $70 \%$ pada nilai $\mathrm{K}=$ $5, K=9, K=10$, dan $K=11$. Di samping itu, juga diperoleh hasil bahwa fusi informasi mampu mempercepat pengenalan jenis tanaman Mangga sebesar 0,11 detik.
\end{abstract}

Kata kunci: Fusi Informasi, jenis tanaman Mangga, K-Nearest Neighbor, Kecerdasan Artifisial, sistem pencitraan digital

\section{THE RECOGNITION OF THE TYPE OF MANGO PLANT BASED ON LEAF SHAPE AND TEXTURE USING ARTIFICIAL INTELLIGENCE K-NEAREST NEIGHBOR (KNN) AND INFORMATION FUSION}

\begin{abstract}
Choosing the right desired Mango plant is a challenge faced with various types of the existing Mangifera clan plants. The wrong choice of Mango plant species can end up with buyer disappointment and reduce the trust to the seller because it can be considered as providing the wrong type of plant. This happened because the type of Mango plant can only be identified after it bears fruit. In the effort to reduce such error, a digital imaging system was designed and built for recognizing the types of Mango plants based on the leaf shape and texture using Artificial Intelligence's K-Nearest Neighbor (KNN) combined with Information Fusion to accelerate the classification with a consistent classification results. The image data consists of four kinds of Mango plant leaves, namely Gadung, Lalijiwo, Golek and Irwin. The leaf texture feature was extracted using the Local Binary Pattern (LBP) and Entropy methods, while the leaf shape feature was extracted using the Rectangularity method. The two features are fused as the input for the KNN classifier. Based on the test results, KNN was able to identify the four types of the Mango plant with the highest accuracy of 70\% at values of $K=5, K=9, K=10$, and $K=$ 11. Besides that, it is also obtained a result that, the information fusion is able to speed up the recognition the types of Mango by 0.11 seconds.
\end{abstract}


Keywords: Artificial Intelligence, digital imaging system, Information Fusion, K-Nearest Neighbor, Mango plant type

\section{PENDAHULUAN}

Mangga memiliki nama ilmiah yaitu Mangifera Indica, yang merupakan nama dari buah dan juga pohonnya yang sangat digemari oleh masyarakat karena mengandung banyak vitamin dan menanam pohon Mangga dapat membantu menghijaukan lingkungan (Soffiana \& Prasetyo, 2015). Beragamnya jenis tanaman Mangga menjadikannya tidak mudah untuk dikenali dengan cepat. Terdapat banyak cara untuk mengenali jenis tanaman Mangga diantaranya dengan menunggu tanaman tersebut berbuah dan dari daunnya. Namun alternatif pertama akan memakan waktu lama, maka diperlukan pendekatan lain dimana pengenalan jenis tanaman Mangga dapat dilakukan cepat yakni melalui daunnya. Teknik cepat untuk mengenali jenis tanaman Mangga sangat dibutuhkan agar konsumen tidak kecewa dan penjual dapat tepat memberikan jenis tanaman Mangga yang diminta oleh konsumen.

Banyak cara dapat digunakan untuk mengenali jenis tanaman Mangga diantaranya melalui karakteristik buah atau daunnya. Tantangan yang dihadapi adalah bagaimana cara mengenali jenis tanaman Mangga ketika masih berusia muda dan belum berbuah. Cara yang paling memungkinkan adalah menggunakan parameter daun sebagaimana yang telah dilakukan oleh (Riska, Cahyani, \& Rosadi, 2014) dan (Rusli \& Nasir, 2018) . Di sisi lain juga telah ada beberapa penelitian dengan beragam metode yang digunakan untuk mengenali jenis tanaman buah. Di antara penelitian-penelitian tersebut adalah penelitian (Rahayu, Honainah, \& Pawening, 2016) mengenai pengenalan jenis Mangga melihat bentuk dan tekstur daun menggunakan pengklasifikasi K-Nearest Neighbor (KNN) yang dikombinasikan dengan metode compactness dan circularity untuk ekstraksi fitur bentuk, dan metode Gray Level Co-Occurrence Matrix (GLCM) untuk ekstraksi fitur tekstur.

Penelitian (Sutarno, Abdullah, \& Passarella, 2017) mengenai identifikasi tanaman buah melalui fitur bentuk, warna dan tekstur daun berbasis pengolahan citra. Ekstraksi fitur bentuk dilakukan dengan metode slimness, roundness, rectangularity, narrow factor, rasio keliling, diameter dan rasio perimeter. Ekstraksi fitur warna dilakukan dengan metode mean, skewness dan kurtosis dan metode contrast, correlation, energy untuk fitur tekstur. Klasifikasi dilakukan oleh metode Kecerdasan Artifisial Learning Vector Quantization (LVQ). Euclidean distance dijadikan sebagai pengklasifikasi untuk identifikasi daun tanaman jeruk berdasarkan fitur tekstur dan bentuk. Kedua fitur diperoleh dengan mengaplikasikan metode Local Binary Pattern (LBP) untuk ekstraksi fitur tekstur dan Moment Invariant untuk ekstraksi fitur bentuk.
Memperhatikan permasalahan di atas, melalui penelitian ini dirancang dan diimplementasikan sebuah aplikasi pengklasifikasi jenis tanaman Mangga berdasarkan pada bentuk dan tekstur dari daun menggunakan pengklasifikasi KNN yang dikombinasikan dengan fusi informasi. Fitur bentuk dan fitur tekstur dari daun Mangga akan diperoleh dari pengolahan citra menggunakan metode Rectangularity dan metode LBP. Perbedaan penting penelitian ini dengan penelitian sejenis adalah penggunaan metode fusi informasi dengan tujuan untuk meningkatkan akurasi hasil klasifikasi dan kecepatan pengenalan jenis tanaman Mangga.

\section{METODE PENELITIAN}

Dalam metodologi penelitian ini akan disampaikan data yang digunakan dalam penelitian, cara pengambilan dan pengolahan data, tata cara melakukan pelatihan dan pengujian sistem serta cara mengukur kinerja sistem.

\subsection{Data Penelitian}

Data citra yang diolah atau dijadikan obyek dari penelitian ini adalah citra daun Mangga dari jenis Mangga Gadung, Mangga Lalijiwo, Mangga Golek dan Mangga Irwin yang semuanya berwarna hijau tua. Masing-masing jenis tanaman Mangga diwakili oleh 30 data citra dengan total data citra sebanyak 120 buah. Contoh citra dari masingmasing jenis daun diperlihatkan pada Gambar 1.

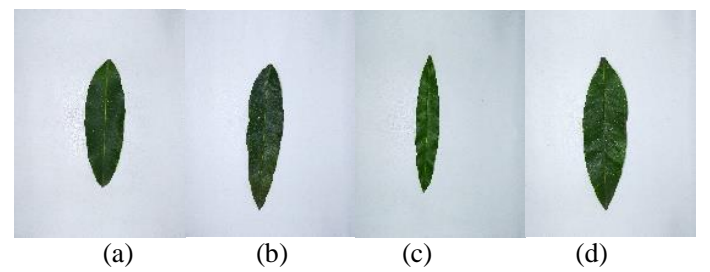

Gambar 1. Contoh data daun Mangga (a) Gadung, (b) Golek, (c) Irwin dan (d) Lalijiwo.

\subsection{Metode Pengambilan Data}

Metode pengambilan data dilakukan dengan cara melakukan observasi ke tempat penjualan bibit Mangga atau masyarakat yang telah melakukan budidaya tanaman Mangga. Pengambilan data juga dilakukan dengan melakukan wawancara dengan para petani tanaman Mangga terkait cara membedakan jenis tanaman Mangga dengan indikator daunnya.

Data-data citra daun Mangga diperoleh dengan cara mengambil foto daun-daun tersebut pada sebuah kotak yang telah dirancang khusus untuk penelitian ini. Kotak tersebut diberikan lapisan latar belakang berwarna putih dan pengambilan foto 
menggunakan kamera telepon genggam bermerek ASUS Zenfone Max Pro M1 dengan jarak antara obyek dan kamera yaitu $28 \mathrm{~cm}$. Tujuannya pembuatan kotak ini adalah untuk menjamin kesamaan kualitas semua citra daun Mangga yang difoto.

\subsection{Metode Pengolahan Citra}

\section{a. Metode Rectangularity}

Perhitungan metode Rectangularity yaitu membagi luas obyek dengan luas area dari obyek tersebut. Langkah-langkah perhitungan metode Rectangularity dapat dilihat pada Gambar 2.

\section{b. Metode LBP}

Perhitungan metode LBP yaitu menggunakan jendela berukuran $3 \times 3$. Proses selanjutnya adalah menentukan nilai tengah dan tetangga kemudian membandingkan nilai tetangga dengan nilai tengah. Jika nilai tetangga $>$ dari nilai tengah maka diberi nilai 1 , dan jika sebaliknya yakni nilai tetangga $\leq$ nilai tengah maka diberi nilai 0 . Nilai-nilai biner tersebut kemudian diubah menjadi nilai desimal. Contoh komputasi LBP diperlihatkan pada Gambar 3. Berdasarkan pada angka-angka dalam kotakkotak tersebut, maka nilai LBP dari sebuah piksel tertentu adalah $0+2+4+8+16+32+0+128$ $=190$.

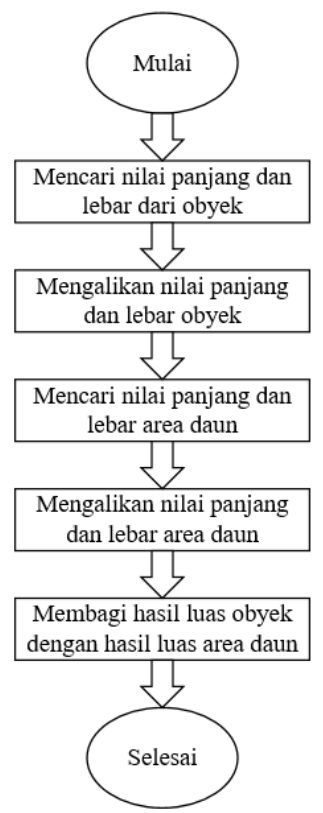

Gambar 2. Tahapan proses metode Rectangularity.

Pada Gambar 2 dapat dilihat bahwa metode Rectangularity dimulai dengan mencari nilai panjang dan lebar dari obyek daun, lalu mendapatkan nilai luas obyek daun dengan mengalikan nilai panjang dengan nilai lebar dari obyek daun. Tahapan berikutnya adalah mencari nilai panjang dan lebar dari area daun atau daerah yang mengelilingi obyek daun. Nilai luas area daun diperoleh dari perkalian nilai panjang dan lebar area daun yang telah didapatkan diikuti dengan membagi nilai luas obyek daun dengan nilai luas area daun.

Pada Gambar 3 dapat diperhatikan bahwa metode LBP dimulai dengan membandingkan nilai piksel tetangga dengan nilai piksel tengah. Apabila nilai piksel tetangga > nilai piksel tengah maka diberi nilai 1 , dan sebaliknya bila nilai piksel tetangga $<$ nilai piksel tengah maka diberi nilai 0 . Nilai-nilai tersebut dimasukkan ke dalam angka 8 bit sesuai arah jarum jam. Nilai piksel tetangga yang telah diubah menjadi angka 8 bit, ditotal untuk menggantikan nilai piksel tengah.

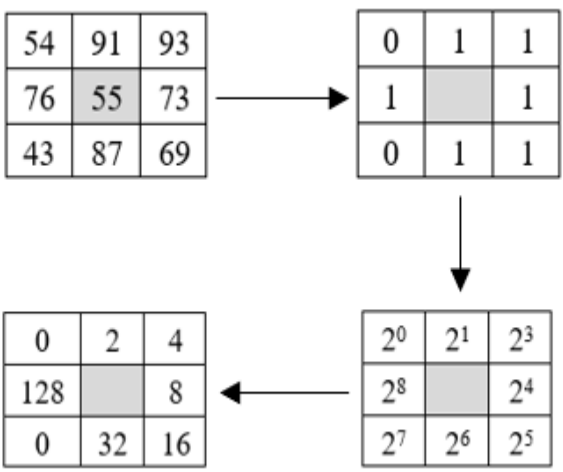

Gambar 3. Alur perhitungan metode LBP.

\subsection{Metode Pengenalan Citra}

Kunci utama dari klasifikasi menggunakan metode KNN adalah fitur. Semakin bagus fitur yang diperoleh maka semakin akurat hasil klasifikasinya. Pada penelitian ini, data citra akan dibagi ke dalam dua dataset yakni dataset untuk pelatihan dan dataset untuk pengujian. Data citra dari masingmasing jenis daun tanaman Mangga dipilah menjadi 25 data citra untuk dataset pelatihan dengan total 100 data citra, dan 5 data citra untuk dataset pengujian dengan total 20 data citra. Mekanisme pelatihan dan pengujian pengklasifikasi KNN diperlihatkan pada Gambar 4 dan Gambar 5.

Pada Gambar 4, pelatihan pengklasifikasi KNN dimulai dengan memasukkan masing-masing data citra ke sistem. Citra tersebut kemudian dilakukan pengolahan awal yang melibatkan proses-proses antara lain mengubah ukuran citra (resize), mengubah citra ke skala keabuan (grayscale), memisahkan citra dengan latar belakangnya (thresholding) dan mengambil wilayah dari data citra yang diperlukan (cropping). Selanjutnya dilakukan ekstraksi fitur pada citra yang dipotong tersebut menggunakan metode rectangularity guna memperoleh fitur bentuk dan menggunakan metode LBP untuk memperoleh fitur tekstur untuk kemudian dihitung nilai entropinya. Sebelum 
digunakan untuk pelatihan dan pengujian, kedua fitur tersebut difusikan terlebih dulu dengan metode fusi informasi operator $A N D$ guna memperoleh fitur tunggal sebagai masukan bagi pengklasifikasi KNN. Setelah pelatihan selesai, pengetahuan KNN terhadap dataset yang dilatihkan disimpan ke dalam sebuah basis pengetahuan.
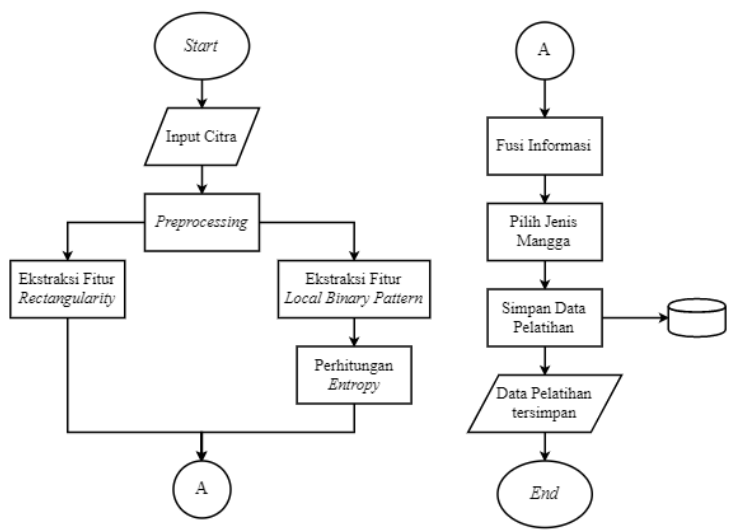

Gambar 4. Diagram alur pelatihan sistem.

Pada Gambar 5, sama halnya proses yang dilalui pada tahap pelatihan, pengujian KNN dimulai dengan memasukkan masing-masing data citra ke sistem. Citra tersebut kemudian dilakukan proses pengolahan awal (preprocessing) yaitu resize, grayscale, thresholding, cropping. Selanjutnya dilakukan ekstraksi fitur pada citra yang dipotong tersebut menggunakan metode rectangularity guna memperoleh fitur bentuk dan menggunakan metode LBP untuk memperoleh fitur tekstur untuk kemudian dihitung nilai entropinya, kemudian dilakukan proses penggabungan dua nilai ekstraksi fitur menggunakan fusi informasi.

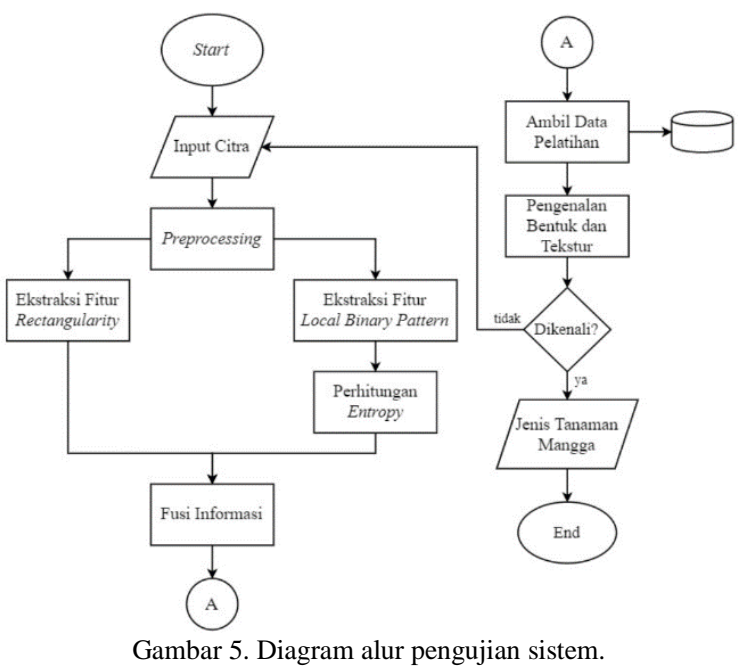

Sebelum melakukan pengenalan citra, sistem mengambil data latih yang telah diperoleh. menguji data uji yang telah dihasilkan oleh sistem pada data latih. Proses pengenalan dilakukan dimana KNN membandingkan pengetahuan yang telah diperolehnya dengan citra-citra dalam dataset pengujian. Apabila citra dikenali, maka akan dihasilkan luaran (output) yaitu jenis tanaman Mangga. Apabila tidak dikenali, maka sistem akan mengulang kembali proses memasukkan (input) citra hingga semua citra dalam dataset telah diujikan semua.

\subsection{Metode Fusi Informasi}

Fusi informasi merupakan salah satu teknik untuk ekstraksi pengetahuan dari sekumpulan data atau informasi guna menghasilkan pengetahuan baru (Sumari \& Ahmad, 2017). Salah satu mode dalam fusi informasi adalah Feature In-Feature Out (FEIFEO) (Sumari \& Ahmad, 2008) yang digunakan dalam penelitian ini. FEI-FEO diterapkan untuk menghasilkan fitur terfusi, setelah itu fitur terfusi FEO digunakan sebagai masukan pengklasifikasi KNN guna memperoleh prediksi jenis tanaman Mangga. Secara umum kedua mode ini diperlihatkan pada Persamaan (1) dan Persamaan (2).

$$
\text { Fitur_terfusi }=\text { Fitur }(i) \oplus \operatorname{Fitur}(i+1)
$$

Bila Fitur $(i)=$ bentuk dan Fitur $(i+1)=$ tekstur, maka:

$$
\text { Fitur_terfusi }=\text { Fitur }(\text { bentuk }) \oplus \text { Fitur (tekstur })
$$

dengan $\bigoplus$ adalah operator fusi informasi berupa operator digital sederhana seperti $A N D$ atau XOR.

$$
\begin{array}{r}
\text { Prediksi }(i)=\text { Fitur_terfusi }(i) \\
\Rightarrow \text { Pengklasifikasi }
\end{array}
$$

Prediksi $(i)$ adalah prediksi jenis tanaman Mangga berdasarkan nilai Fitur_terfusi(i) yang diklasifikasikan oleh Pengklasifikasi, yang dalam penelitian ini adalah KNN. Mekanisme yang dituangkan dalam Persamaan (1) dan Persamaan (2) diilustrasikan pada Gambar 6.

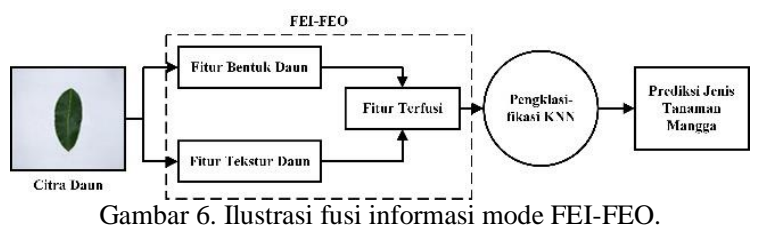

\subsection{Metode Pengukuran Kinerja Sistem}

Pengujian akurasi merupakan pengujian yang dilakukan untuk menguji tingkat keakuratan atau kesesuaian dari data uji yang dihasilkan oleh sistem dengan data yang didapat dari pakar. Nilai akurasi didapatkan dari perhitungan Persamaan (3).

$$
\text { Akurasi }=\frac{(T P+T N)}{(T P+F P+F N+T N)}
$$


Pada Persamaan 1, terdapat 4 istilah yaitu True Positive (TP) yang artinya data positif yang diprediksi benar, True Negative (TN) yang artinya data negatif yang diprediksi benar, False Positive (FP) yang artinya data negatif namun diprediksi sebagai data positif, False Negative (FN) yang artinya data positif namun diprediksi sebagai data negatif (Nugroho, 2019).

\section{HASIL DAN PEMBAHASAN}

Pada bagian ini disampaikan implementasi sistem ke bentuk sebuah aplikasi program komputer. Gambar 7 memperlihatkan antarmuka sistem saat akan menerima data citra daun Mangga yang akan diproses ke dalam sistem guna mengetahui jenis pohon Mangganya.

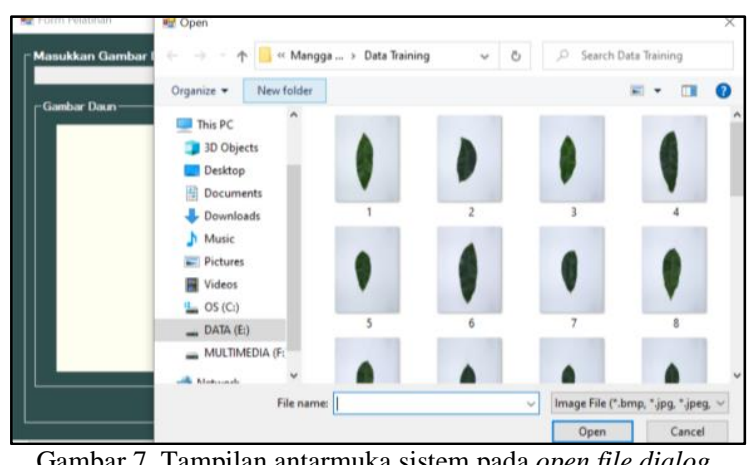

\subsection{Pengolahan Citra}

Pada Gambar 8 diperlihatkan pengolahan citra tahap demi tahap pada salah satu jenis daun Mangga dalam dataset yakni daun Mangga gadung. Gambar 8(a) memperlihatkan citra daun asli yang belum dilakukan proses apapun. Gambar 8(b) memperlihatkan citra daun yang diperoleh dari hasil pengubahan ukuran citra (resize). Pada sistem pencintraan digital ini, citra akan diubah ke ukuran $600 \times 600$ piksel.

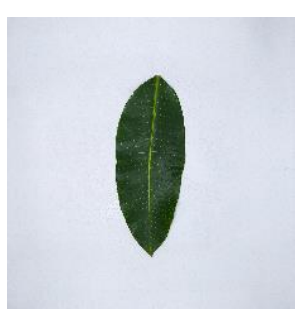

(a)

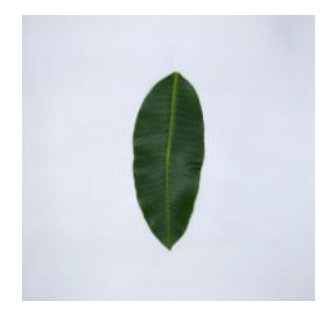

(b)
Gambar 8. (a) Citra asli daun Mangga gadung, (b) Citra hasil pengubahan ke piksel.

Pada Gambar 8(c) diperlihatkan citra daun hasil proses grayscale yang diperoleh dari pengubahan citra RGB menjadi citra dengan level keabuan. Gambar 8(d) memperlihatkan citra daun yang diperoleh dari hasil binarization, yakni teknik untuk mengubah citra yang semula memilik level keabuan menjadi citra dengan hanya dua macam warna yakni hitam dan putih atau citra 2 bit dengan nilai masing-masing adalah 1 dan 0 . Gambar 8(e) merupakan citra daun yang diperoleh dari hasil cropping, yaitu teknik untuk menghilangkan area tertentu yang tidak diperlukan pada citra daun.

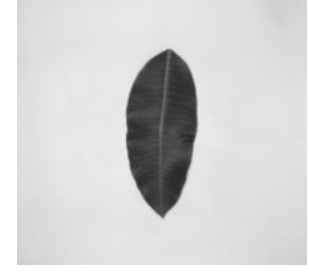

(c)

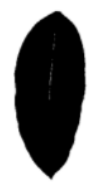

(d)
Gambar 8. (c) Citra hasil pengubahan ke level keabuan, (d) Citra hasil dari binarization.

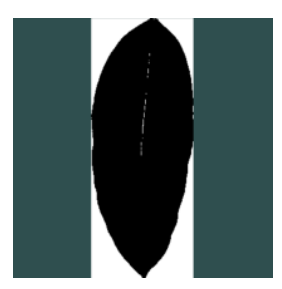

(e)

Gambar 8. (e) Citra hasil pemotongan wilayah yang tidak diperlukan.

\subsection{Ekstraksi Fitur}

Ekstraksi fitur menggunakan dua metode berbeda untuk memperoleh dua macam fitur yakni bentuk daun dan tekstur daun. Fitur bentuk daun diperoleh melalui metode rectangularity, sedangkan fitur tekstur diperoleh dari kombinasi LBP dan entropi. Kedua macam fitur tersebut beserta hasil fusi kedua fitur tersebut dalam bentuk fitur terfusi diperlihatkan pada Tabel 1, Tabel 2, dan Tabel 3.

Tabel 1 menyampaikan beberapa contoh hasil dari proses ekstraksi fitur bentuk menggunakan metode Rectangularity yang didapatkan dari pembagian luas objek daun dengan luas area daun.

Pada Tabel 2 diperlihatkan contoh hasil proses metode LBP pada citra daun yang kemudian dihitung nilai entropinya. Citra LBP dihasilkan dari perbandingan piksel tetangga dengan piksel tengah, lalu mengubah nilai piksel menjadi 1 dan 0 , kemudian diubah kembali menjadi nilai piksel 8 bit, dan terakhir menjumlahkan nilai-nilai tersebut untuk menggantikan nilai piksel tengah. Pada Tabel 3 disampaikan contoh-contoh hasil dari fusi informasi.

Nilai Rectangularity yang diperoleh dari ekstraksi fitur bentuk daun dan nilai Entropi yang diperoleh dari ekstraksi fitur tekstur digabungkan menjadi satu nilai fitur baru yaitu nilai fitur terfusi yang akan menjadi masukan bagi pengklasifikasi KNN. Fitur utama dari sistem pencitraan digital untuk pengenalan jenis tanaman Mangga ini terletak pada pemanfaatan fusi informasi untuk menghasilkan fitur terfusi yang telah merepresentasikan baik fitur bentuk daun maupun fitur tekstur daun.

Fitur tersebut tidak dimiliki oleh sistem pencitraan digital untuk pengenalan objek sejenis, yakni menggunakan dua macam fitur berbeda untuk 
pengenalan jenis tanaman Mangga. Secara umum, belum ada sistem pencitraan digital untuk pengenalan jenis tanaman yang setara dengan sistem yang dirancang dan dibangun dalam penelitian ini.

Tabel 1. Fitur bentuk daun hasil komputasi metode rectangularity

\begin{tabular}{|c|c|c|}
\hline Jenis Mangga & Citra Daun & Nilai Rectangularity \\
\hline Gadung & & 0,132 \\
\hline Golek & & 0,14 \\
\hline Irwin & & 0,079 \\
\hline Lalijiwo & & 0,176 \\
\hline
\end{tabular}

Tabel 2. Fitur tekstur daun hasil komputasi metode LBP dan

\begin{tabular}{|c|c|c|c|}
\hline Jenis Mangga & Citra Daun & Hasil LBP & Nilai Entropy \\
\hline Gadung & & & 1,117 \\
\hline Golek & & & 0,923 \\
\hline Irwin & & & 0,433 \\
\hline Lalijiwo & & & 0,673 \\
\hline
\end{tabular}

\subsection{Pelatihan dan Pengujian Sistem}

Antarmuka pelatihan sistem diperlihatkan pada Gambar 9, sedangkan tampilan antarmuka hasil ekstraksi fitur diperlihatkan pada Gambar 10. Pada antarmuka ekstraksi fitur, terdapat tombol "Ekstraksi Fitur" digunakan untuk melakukan proses pengolahan awal dilanjutkan dengan ekstraksi fitur bentuk dan ekstraksi fitur tekstur dari citra daun tanaman Mangga yang dimasukkan ke sistem.

Tabel 3. Nilai fitur terfusi hasil dari fusi fitur bentuk daun dan

\begin{tabular}{cccc} 
Jenis & $\begin{array}{c}\text { Nilai Fitur } \\
\text { Bentuk } \\
\text { Daun }\end{array}$ & $\begin{array}{c}\text { Nilai Fitur } \\
\text { Tekstur } \\
\text { Daun }\end{array}$ & $\begin{array}{c}\text { Nilai Fitur } \\
\text { Terfusi }\end{array}$ \\
\hline Gadung & 0,132 & 1,117 & 0,131 \\
Golek & 0,141 & 0,923 & 0,125 \\
Irwin & 0,079 & 0,433 & 0,016 \\
Lalijiwo & 0,176 & 0,673 & 0,039 \\
\hline
\end{tabular}

Nilai dari hasil-hasil ekstraksi fitur tersebut ditampilkan pada masing-masing textbox yang bersesuaian. memperlihatkan tampilan antarmuka dari pelatihan sistem.

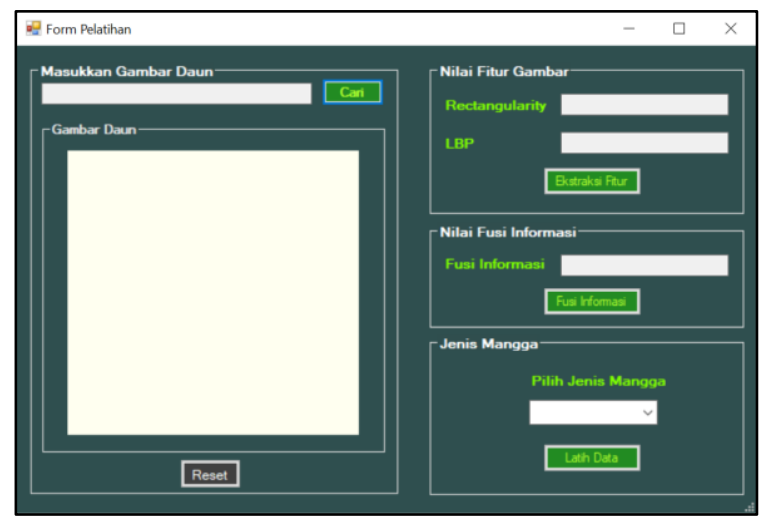

Gambar 9. Tampilan antarmuka pelatihan sistem

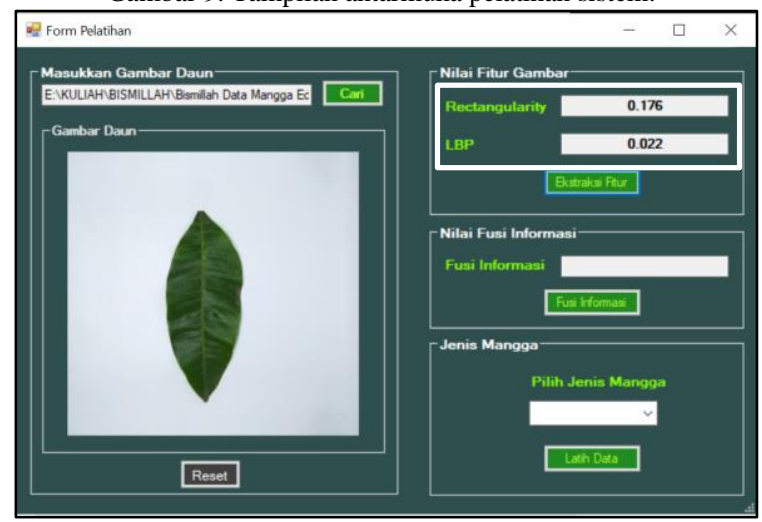

Gambar 10. Tampilan antarmuka ekstraksi fitur.

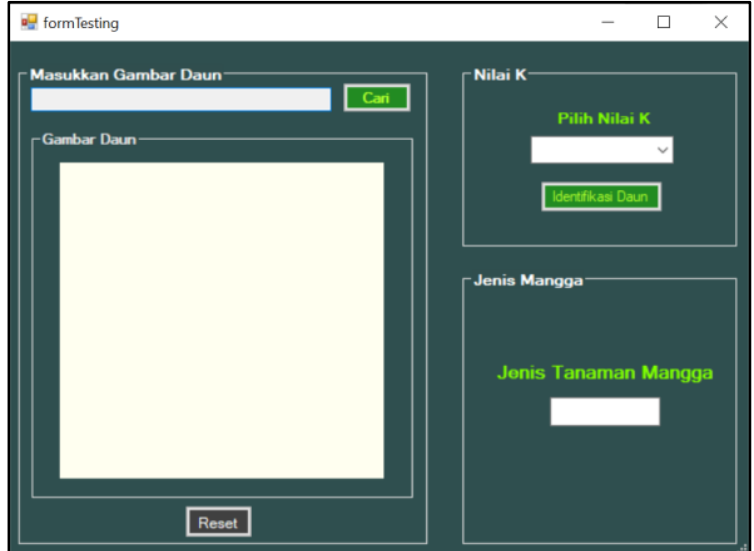

Gambar 11. Tampilan antarmuka pengujian sistem. 
Tampilan antarmuka pengujian sistem diperlihatkan pada Gambar 11, dimana proses klasifikasi akan dilakukan dilanjutkan dengan menampilkan hasil dari klasifikasi. Pada halaman pengujian, pengguna dapat memilih nilai $\mathrm{K}$ yang akan digunakan untuk klasifikasi. Tampilan antarmuka hasil dari klasifikasi menggunakan KNN diperlihatkan pada Gambar 12, dimana hasil klasifikasi akan ditampilkan di dalam textbox yang tersedia berupa jenis tanaman Mangga yang sesuai dengan pengetahuan yang telah dimiliki oleh KNN.

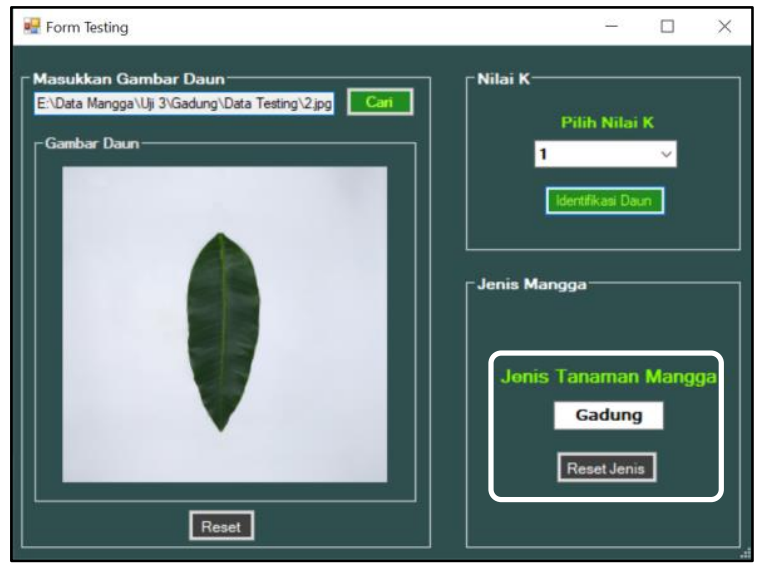

Gambar 12. Tampilan hasil klasifikasi KNN.

Sebagaimana telah disampaikan pada bagian sebelumnya, pengujian dilakukan perbandingan data $83,3 \%: 16,7 \%$ yaitu data latih sebanyak masingmasing jenis daun adalah 25 citra dan data latih sebanyak 5 citra, atau total 100 citra untuk pelatihan sistem dan 20 citra untuk pengujian sistem (120 data). Pengujian juga dilakukan dengan membandingkan kinerja sistem pengklasifikasi menggunakan fitur terfusi dan menggunakan fitur masing-masing. Pemilihan perbandingan data yang digunakan, mengacu pada penelitian terdahulu yang dilakukan oleh (Ananta, Batubulan, \& Wildani, 2019).

\subsection{Hasil-Hasil Pengujian Sistem dan Akurasi Hasil Klasifikasi}

Pada Tabel 4 disampaikan rangkuman/ ringkasan dari hasil-hasil pengujian sistem pengklasifikasi KNN dengan masukan berupa nilai fitur terfusi, sedangkan pada Tabel 5 menampilkan rangkuman hasil-hasil pengujian sistem pengklasifikasi KNN dengan masukan berupa nilai fitur tidak terfusi.

Dari hasil-hasil pengujian sistem dengan fitur terfusi dapat dikalkulasi bahwa akurasi hasil klasifikasi tertinggi adalah sebesar $70 \%$ dengan $\mathrm{K}=$ $5, \mathrm{~K}=9, \mathrm{~K}=10$ dan $\mathrm{K}=11$. Waktu komputasi yang dibutuhkan untuk melakukan klasifikasi menggunakan masukan fitur terfusi adalah sebesar 6,40 detik. Sebaliknya, hasil pengujian sistem dengan fitur masing-masing atau tidak terfusi diperoleh akurasi klasifikasi tertinggi sebesar $75 \%$ dengan $\mathrm{K}=5$. Di sisi lain, waktu komputasi yang digunakan adalah sebesar 6,51 detik. Terdapat perbedaan kecepatan komputasi antara klasifikasi menggunakan masukan berupa fitur terfusi dengan tidak terfusi sebesar 0,11 detik.

Tabel 4. Hasil pengujian sistem dengan masukan berupa fitur terfusi.

\begin{tabular}{ccc}
\hline Nilai K & Akurasi & Total \\
\hline $\mathrm{K}=1$ & $\frac{13+0}{13+7+0+0}$ & $0,65(65 \%)$ \\
$\mathrm{K}=3$ & $\frac{13+0}{13+7+0+0}$ & $0,65(65 \%)$ \\
$\mathbf{K}=\mathbf{5}$ & $\frac{\mathbf{1 4 + 0}}{\mathbf{1 3 + 7 + 0 + 0}}$ & $\mathbf{0 , 7}(\mathbf{7 0} \%)$ \\
$\mathrm{K}=7$ & $\frac{12+0}{13+7+0+0}$ & $0,6(60 \%)$ \\
$\mathrm{K}=\mathbf{9}$ & $\frac{\mathbf{1 4 + 0}}{\mathbf{1 3 + 7 + 0 + 0}}$ & $\mathbf{0 , 7}(\mathbf{7 0} \%)$ \\
$\mathrm{K}=\mathbf{1 0}$ & $\frac{\mathbf{1 4 + 0}}{\mathbf{1 3 + 7 + 0 + 0}}$ & $\mathbf{0 , 7 ( 7 0 \% )}$ \\
$\mathrm{K}=\mathbf{1 1}$ & $\frac{\mathbf{1 4 + 0}}{\mathbf{1 3 + 7 + 0 + 0}}$ & $\mathbf{0 , 7}(\mathbf{7 0} \%)$ \\
\hline
\end{tabular}

Tabel 5. Hasil pengujian sistem dengan masukan berupa fitur tidak terfusi.

\begin{tabular}{ccc}
\hline Nilai $\mathrm{K}$ & Akurasi & Total \\
\hline $\mathrm{K}=1$ & $\frac{12+0}{12+8+0+0}$ & $0,60(60 \%)$ \\
$\mathrm{K}=3$ & $\frac{14+0}{14+6+0+0}$ & $0,7(70 \%)$ \\
$\mathbf{K}=\mathbf{5}$ & $\frac{\mathbf{1 5 + 0}}{\mathbf{1 5 + 5 + 0 + 0}}$ & $\mathbf{0 , 7 5 ( 7 5 \% )}$ \\
$\mathrm{K}=7$ & $\frac{11+0}{11+9+0+0}$ & $0,55(55 \%)$ \\
$\mathrm{K}=9$ & $\frac{13+0}{13+7+0+0}$ & $0,65(65 \%)$ \\
$\mathrm{K}=10$ & $\frac{12+0}{12+8+0+0}$ & $0,60(60 \%)$ \\
$\mathrm{K}=11$ & $\frac{12+0}{12+8+0+0}$ & $0,60(60 \%)$ \\
\hline
\end{tabular}

\subsection{Analisa}

Pada penelitian ini, pemilihan nilai fitur yang menjadi acuan untuk klasifikasi menggunakan KNN yaitu fitur bentuk daun dan fitur tekstur daun. Hal didasarkan pada pertimbangan bahwa bentuk dan tekstur dari beragam jenis daun lebih berpotensi berbeda satu dengan lainnya. Berbeda halnya dengan fitur warna pada daun yang mana jenis satu daun dengan lainnya berpotensi memiliki kesamaan yaitu berwarna hijau (Paturrahman, 2020).

Dalam penelitian ini, kebaruan yang dihasilkan adalah penggunaan fusi informasi untuk meningkatkan kinerja pengklasifikasi KNN dalam melakukan proses klasifikasi. Fusi Informasi akan menghasilkan satu nilai fitur terfusi yang telah merepresentasikan semua nilai fitur yang difusikan. 
Nilai fitur terfusi ini yang menjadi masukan bagi sistem untuk digunakan pada klasifikasi.

Akurasi klasifikasi dari sistem pengenalan jenis tanaman Mangga berdasarkan bentuk dan tekstur daun dilakukan menggunakan bantuan confusion matrix dan Persamaan (3). Dari kedua macam pengujian yang telah dilakukan yaitu pengujian sistem dengan masukan berupa fitur terfusi dan tanpa fitur terfusi, diperoleh akurasi tertinggi terfusi adalah $70 \%$ untuk fitur terfusi dan $75 \%$ untuk fitur tidak terfusi.

Nilai optimal K untuk masukan berupa fitur terfusi adalah $\mathrm{K}=11$ dengan akurasi sebesar $70 \%$ sedangkan untuk masukan berupa fitur tidak terfusi hanya sebesar $60 \%$. Berdasarkan konsep $\mathrm{K}$ dalam KNN, untuk setiap data baru yang diberikan ke pengklasifikasi maka $\mathrm{K}$ menjadi penentu jumlah tetangga dari data baru tersebut yang digunakan untuk memperhalus estimasi guna menempatkannya pada kelas yang tepat (Farrelly, 2017). Klasifikasi menggunakan fitur terfusi menunjukkan konsistensi lebih tinggi dibandingkan dengan yang menggunakan fitur tidak terfusi. Hal ini menunjukkan bahwa fusi informasi memainkan peran penting dalam menjaga konsistensi pengenalan data-data baru oleh sistem ini.

Hal yang kedua, dari penelitian ini diperlihatkan bahwa fusi informasi berperan penting untuk menyederhanakan dan mempersingkat proses klasifikasi. Dengan menggunakan fitur terfusi atau satu nilai fitur sebagai acuan, sistem mampu melakukan pengenalan citra daun Mangga 0,11 detik lebih cepat dibandingkan dengan masukan berupa fitur tidak terfusi. Fusi informasi akan memberikan dampak signifikan saat sistem diberikan data citra dalam jumlah yang sangat banyak. Sebagai contoh sistem diberikan data baru sebanyak 10.000 citra, maka sistem ini akan mampu menghemat waktu sebesar 1.100 detik atau 18,33 menit. Perbedaan waktu yang sangat signifikan bagi sebuah sistem pengenalan berbasis teknologi Kecerdasan Artifisial.

\section{KESIMPULAN DAN LANGKAH KEDEPAN}

\subsection{Kesimpulan}

Berdasarkan penjelasan yang telah disampaikan di atas, dapat diambil kesimpulan sebagai berikut:

1. Sistem pencitraan digital untuk pengenalan jenis tanaman Mangga menggunakan masukan berupa fitur terfusi dari fitur bentuk daun dan tekstur daun berhasil memberikan konsistensi hasil yang lebih tinggi dibandingkan dengan masukan berupa fitur tidak terfusi.

2. Nilai $\mathrm{K}$ optimal untuk klasifikasi dengan fitur terfusi adalah $\mathrm{K}=11$ dengan akurasi tertinggi sebesar $70 \%$, dimana untuk fitur tidak terfusi hanya mencapai $60 \%$.
3. Fusi informasi mampu mempercepat waktu pengenalan jenis tanaman Mangga sebesar 0,11 detik dibandingkan dengan tanpa fusi informasi.

\subsection{Langkah Kedepan}

Berdasarkan kesimpulan di atas, langkahlangkah kedepan untuk menyempurnakan sistem pengenalan yang telah diimplementasikan dan diuji ini adalah sebagai berikut:

1. Meningkatkan akurasi pengenalan dengan menggunakan metode ekstraksi fitur yang lebih representatif atau melalui kombinasi dua atau lebih metode agar memperoleh fitur dari hasil ekstraksi yang lebih representatif.

2. Menguji coba metode fusi informasi lain, misalnya XOR atau metode fusi penginferensian informasi ASSA2010 (Sumari \& Ahmad, 2017), guna memperoleh fitur terfusi yang lebih representatif.

3. Mengembangkan sistem pengenalan ini berbasiskan aplikasi mobile guna memberikan fleksibilitas tinggi baik bagi para pengguna terutama calon pembeli tanaman Mangga maupun penjualnya.

\section{DAFTAR PUSTAKA}

ACHSANI, F.N., ATMAJA, R.D., \& PURNAMASARI, R., 20153. Deteksi Adanya Cacat Pada Kayu Menggunakan Metode Local Binary Pattern. e-Proceeding of Engineering, 2(1), pp. 298-305.

ANANTA, A.Y., BATUBULAN, K.S., \& WILDANI, A.N.R., 2019. Klasifikasi Tingkatan Mutu Buah Manggis berdasarkan Warna dan Diameter menggunakan Metode K-Nearest Neighbor. Jurnal Informatika Polinema, 5(2). pp. 6773 [online]. Tersedia di: < http://jip.polinema.ac.id/ojs3/index.php/jip/ article/view/239> [Diakses 5 April 2020]

CHUNG-MING, K., NAI-CHUNG, Y., CHINSHAN, L., JING-YAN, L. \& CHEN, Y., 2010. Global Image Enhancement in DCT Domain. IEEE, pp. 521-525

FARRELLY, C.M., 2017. KNN Ensembles for Tweedie Regression: The Power of Multiscale Neighborhoods [online]. Tersedia <https://arxiv.org/abs/1708.02122> [Diakses 23 Juli 2020].

NADKARNI, P., 2016. Core Technologies: Data Mining and Big Data. Clinical Research Computing, 187-204 [online]. Tersedia di: <https://doi.org/10.1016/b978-0-12803130-8.00010-5> [Diakses 20 Mei 2020] 
NUGROHO, K.S., 2019. Confusion Matrix untuk Evaluasi Model pada Supervised Learning [online] Tersedia di <https://medium.com/@ksnugroho/confusi on-matrix-untukevaluasi-model-padaunsupervised-machine-learning [Diakses 8 Agustus 2020]

PATURRAHMAN, A.A., 2020. Tugas Akhir S-1: Analisis Pengenalan Pola Daun Berdasarkan Fitur Canny Edge Detection dan Fitur GLCM Menggunakan Metode Klasifikasi K-Nearest Neighbor (K-NN) [online]. Tersedia di: < http://begawe.unram.ac.id/index.php/ta/arti cle/view/79> [Diakses 6 Juli 2020]

RAHAYU, P.A., HONAINAH, \& PAWENING, E. R., 2016. Klasifikasi Jenis Mangga Berdasarkan Bentuk dan Tekstur Daun Menggunakan Metode K-Nearest Neighbor. Prosiding SENTIA, 8. pp. A247A253 [online]. Tersedia di: $<$ https://prosiding.polinema.ac.id/sentia/ind ex.php/SENTIA2016/article/viewFile/49/44 $>$ [Diakses 4 April 2020].

RISKA, S.Y., CAHYANI, L., \& ROSADI, M.I. (2015). Klasifikasi Jenis Tanaman Mangga Gadung dan Mangga Madu Berdasarkan Tulang Daun. Jurnal Buana Informatika, 6(1), pp. 41-50 [online]. Tersedia di: < https://ojs.uajy.ac.id/index.php/jbi/article/vi ew/399> [Diakses 4 April 2020].

RUSLI \& NASIR, M., 2018. Klasifikasi Jenis Mangga Berdasarkan Bentuk Daun Menggunakan Metode K-Nearest Neighbor. Jurnal Infomedia, 3(2), pp. 87 91 [online]. Tersedia di: < http://ejurnal.pnl.ac.id/index.php/infomedia/article /view/1315> [Diakses 8 April 2020].
SOFFIANA, A., \& PRASETYO, E., 2015. Klasifikasi Jenis Pohon Mangga Gadung dan Curut Berdasarkan Tekstur Daun. SESINDO 2011, Desember 2011. pp. 1-8, [online]. Tersedia di: < http://repository.ubhara.ac.id/files/UBHAR ASURYA-Proceeding-45-

U74KlasifikasiJenisManggaBerdasarkanTe ksturDaun.pdf> [Diakses 4 April 2020]

SUMARI, A.D.W., \& AHMAD, A.S., 2008. Designing MultiAgent-based Information Fusion System. The $1^{\text {st }}$ Makassar International Conference on Electrical Engineering and Informatics 2008, pp. 137143.

SUMARI, A.D.W., \& AHMAD, A.S., 2016. The Fusion of Artificial Intelligence and Information Fusion. International Symposium on Electronics and Smart Devices 2016, [online]. Tersedia di: < https://ieeexplore.ieee.org/document/78867 54> [Diakses 21 Mei 2020]

SUMARI, A.D.W., \& AHMAD, A.S., 2017. Information Fusion as Knowledge Extraction in an Information Processing System. International Journal of Artificial Intelligence and Neural Networks, 7(1), pp. 22-27.

SUTARNO, ABDULLAH, R.F., \& PASSARELLA, R., 2017. Identifikasi Tanaman Buah Berdasarkan Fitur Bentuk, Warna dan Tekstur Daun Berbasis Pengolahan Citra dan Learning Vector Quantization ( LVQ ). Prosiding Annual Research Seminar 2017, 3(1), pp. 65-70. 
Halaman ini sengaja dikosongkan 